\title{
Structural Decomposition Analysis of Driving Factors for Energy Use Before and After the Global Financial Crisis: Evidence from Top Energy Consumer Guangdong Province in China
}

\author{
Changjian Wang ${ }^{1 *}$, Fei Wang ${ }^{2}$, Bin Wen ${ }^{3 * *}$, Yuyao Ye ${ }^{1}$, Hongou Zhang ${ }^{1}$ \\ ${ }^{1}$ Key Laboratory of Guangdong for Utilization of Remote Sensing and Geographical Information System, \\ Guangdong Open Laboratory of Geospatial Information Technology and Application, Guangzhou Institute \\ of Geography, Guangdong Academy of Sciences, Guangzhou 510070, China \\ ${ }^{2}$ Xinjiang Laboratory of Lake Environment and Resources in Arid Zone, Research Centre for Urban Development \\ of the Silk Road Economic Belt, College of Geography Science and Tourism, Xinjiang Normal University, \\ Urumqi 830054, Xinjiang, China \\ ${ }^{3}$ College of Economic and Management, Huanghuai University, Zhumadian 463000, China
}

Received: 22 March 2018

Accepted: 24 July 2018

\begin{abstract}
Understanding drivers for energy consumption is important for economic and environmentally sustainable development. To explore this issue, the SDA (structural decomposition analysis) method based on input-output theory was used to analyze the influencing mechanism of energy consumption in one of the top energy consumers, Guangdong Province in China, during 2002 to 2012. We divided the process into 2 stages: before and after the global financial crisis. The main conclusions are as follows:

1) Economic activity and population size are the main driving factors for the increase in energy consumption, while energy consumption intensity is the main factor restraining the increment, and the effects of final demand structure on energy consumption transformed from positive before the global financial crisis to negative after the global financial crisis.

2) Analysis of allocation of energy consumption changes caused by final demands shows that international and domestic trade had significant effects on changes in energy consumption. Although energy consumption embodied in international exports decreased after the global financial crisis, it is still the most significant important driver for the increments. Guangdong is a net exporter of embodied
\end{abstract}

*e-mail: wwwangcj@126.com

**e-mail: yellowriverwenbin@163.com 
energy through international trade, while its energy-saving achievement is partly due to embodied energy transfers via China's domestic trade.

Keywords: structural decomposition analysis (SDA), energy consumption, Guangdong Province, embodied energy transfer, global financial crisis

\section{Introduction}

Abundant energy use has been one of the most important cornerstones of the world's rapid social economic development since the opening of the industrial revolution [1]. Along with continuous economic growth, global total primary energy consumption increased from 3730.23 million tons of oil equivalent (TOE) in 1965 to 12622.09 million TOE in 2012 [2]. Both developed countries/regions (i.e., US, EU, Japan) and developing countries (i.e., China, India) have made great contributions to global energy consumption increments. As the world's largest developing country, China's total energy consumption has accelerated since 2000 with near double-digit annual economic growth. China's total primary energy consumption increased rapidly from 1003.11 million TOE in 2000 (accounting for $10.68 \%$ of global total energy consumption) to 2795.26 million TOE in 2012 (22.15\% of the global total) [2]. Especially, China's total energy consumption surpassed the US after 2009, being the largest energy consumer around the world. Under such circumstances, China has made great efforts to control its total energy consumption and the energy intensity during the past decades [3]. In the newly published $13^{\text {th }}$ Five-Year Plan For Energy Development (2016-2020) and the Energy Production and Consumption Strategy (2016-2030) announced by China's National Development and Reform Commission (NDRC), China's government promised that its total energy consumption would be controlled under 5 billion tons of standard coal equivalent (TCE) in 2020 and 6 billion TCE in 2030, aiming to achieve its energy and emissions peak. To continue to reinforce the energy savings and emission reduction targets, the total national mitigation goals were definitely evaluated and allocated among provinces in the newly published $13^{\text {th }}$ Five-Year Plan for Greenhouse Gas Emissions Control (20162020). Hence, what is the best way to effectively achieve the regional allocation of energy savings and emissions reduction?

As shown in Fig. 1, there were pronounced differences in the total energy consumption and energy consumption structures among provinces within China. Economic development level (per capita GDP) and manufacturing technology level (energy consumption intensity) were also performing significant disparities across the whole country (Fig. 2). Top energy consumption provinces such as Shandong, Hebei, Guangdong, Jiangsu, Henan and Liaoning consumed nearly $40 \%$ of the national total energy consumption. Therefore, there is an urgent need for the bottom-up analysis of energy consumption mechanism and energy saving potential based on the provincial perspective, especially the top provincial energy consumer in China.

In this study, we take Guangdong Province as an example mainly for two reasons: on the one hand, Guangdong Province is one of the top energy consumers in China whose total energy consumption in 2012 was almost equal to the United Kingdom's total energy consumption in the same year. On the other hand, Guangdong was listed as the first batch of lowcarbon pilots by China's NDRC in 2010. As shown in Fig. 3, Guangdong's economic growth and total energy consumption both accelerated after China joined the World Trade Organization in 2001, with near double-digit annual growth rates. Furthermore, Guangdong's contribution of energy consumption to China was still performing an increasing trend. Conversely, Guangdong's contribution of GDP to China decreased obviously, especially after the global financial crisis in 2007. If this situation cannot be reversed effectively, it will present a serious challenge to the energy consumption intensity reduction in Guangdong. Although the impact of the global financial crisis on carbon emissions mainly from fossil-fuel combustion was short-lived, there was strong emissions growth in emerging economies [4]. For example, China's emissions growth rate was $10.4 \%$ in 2010 , while global emissions grow 5.9\% [4]. The main reason underlying this emissions rebound was an increase in the fossilfuel intensity of the world economy [4]. As for China, energy-related carbon emissions flow patterns have changed greatly since the global financial crisis in both international and domestic trade [5]. Especially, China's emissions embodied in exports declined after the global financial crisis. The main reasons underlying these emission declines were changes in production structure and efficiency gains [5]. In terms of China's foreign trade, the global crisis reduced developed countries' (e.g., Spain [6]) imports of pollution-intensive inputs from China, while developing regions became the dominant destination of China's emissions embodied in exports [5]. Therefore, how did these foreign and domestic changes effect energy consumption in Guangdong? In the newly published $13^{\text {th }}$ Five-Year Plan for Greenhouse Gas Emissions Control in Guangdong Province (2016-2020), Guangdong's local government made promises to control the total energy consumption under 0.338 billion TCE by 2020, while energy consumption intensity (defined as a reduction in energy consumption per unit of GDP) 
would decrease by $17 \%$ in 2020 compared with the 2015 level, and the consumption proportion of non-fossil energy would reach $26 \%$ by 2020 . As a consequence, there is an urgent need to have a deeper understanding of the provincial case-based empirical studies to study its driving factors of energy in detail, especially during the rapid change period 2002-2012. Therefore, Guangdong may serve as a demonstration of how to complete the energy savings and emission reduction targets, thereby highlighting the representativeness of Guangdong as an important low-carbon pilot over China.

\section{Material and Methods}

Two kinds of decomposition techniques, namely index decomposing analysis (IDA) and structure decomposing analysis (SDA), have been developed independently and widely applied to uncover the influencing drivers for an aggregate indicator (i.e., total energy consumption). In energy studies, one approach proposed by Myers and Nakamura [7] and Bossanyi [8] are two of the earliest IDA applications to decompose the changes in energy. Since then, the IDA technique has been applied successfully to decompose changes in industrial energy demand $[9,10]$, residential energy consumption [11], total energy consumption

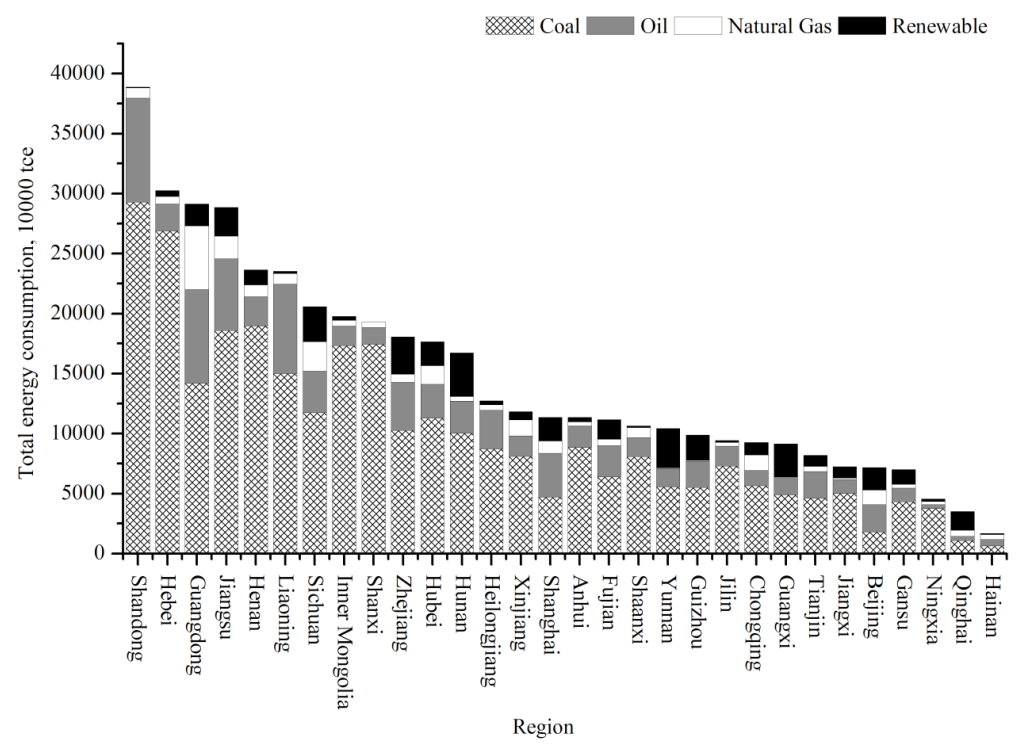

Fig. 1. China's provincial total energy consumption and its consumption structure in 2012.

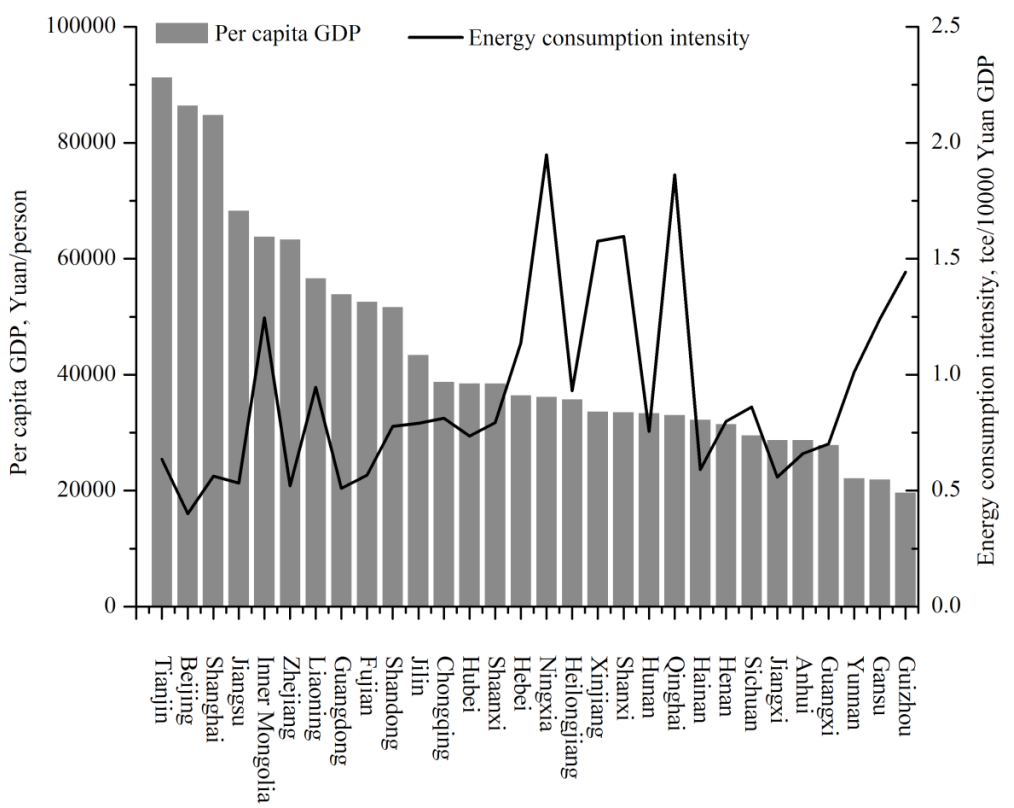

Fig. 2. China's provincial per capita GDP and energy consumption intensity in 2012. 
a)

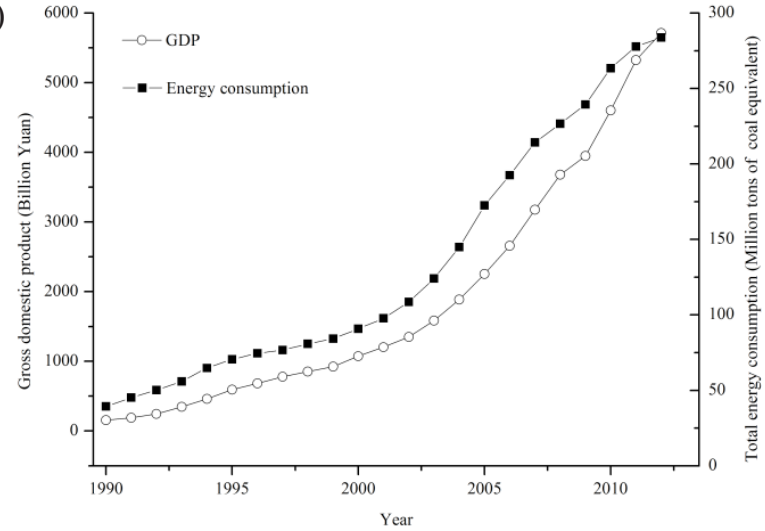

b)

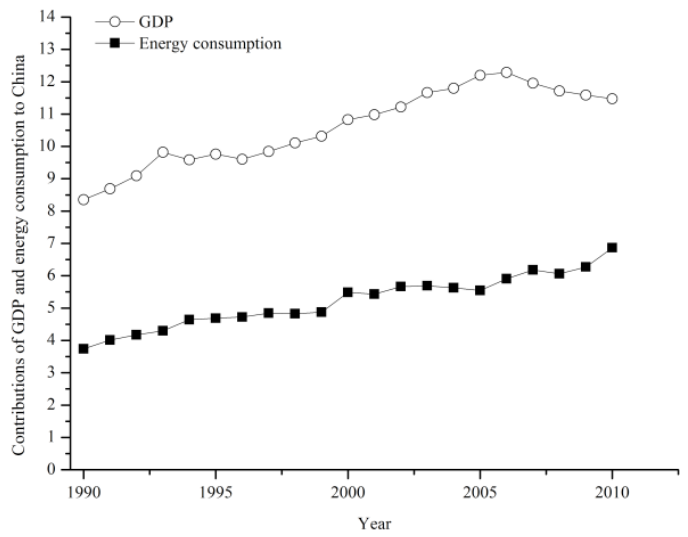

Fig 3. Guangdong's GDP and energy consumption a), and its contributions of GDP and energy consumption to China b) from 1990 to 2012.

[12], energy intensity [13], and energy efficiency [14], because the advantage of IDA is that each model can be applied readily to any available data at any level of aggregation in a period-wise or time-series manner [15-17]. Comprehensive surveys of IDA in energy studies can be found in [18, 19]. SDA and IDA are related [20] and SDA and IDA are consistent in decomposition methods, but differ in the modelling of an aggregate indicator [21]. The IDA method employs data aggregation to analyze the direct effects of changes in various factors on energy consumption, this aggregation limits policy implications to the particular sector level [22]. The SDA model, based on the classical input-output theory [23, 24], features greater data integrity, including the relationship between an economy's production and consumption, which remedies the deficiency of the IDA model for its failure to examine the indirect effects of changes in final demand sectors [25]. The application of the SDA method in energy studies was later than that of IDA, and the SDA method has also been adopted in energy studies since the 1980s [19]. [26-30] are five of the relative earliest SDA applications to decompose the changes in energy. Table 1 exhibits a brief summary of the key developments of SDA applications in energy studies from research conducted from 1980 to the present. Of the selected 38 SDA applications in energy studies listed here, nearly $80 \%$ contain decomposition of changes in energy consumption or embodied energy indicators at the national level. Approximately 20\% deal with the energy intensity indicator. In addition, nearly $40 \%$ of the selected studies were conducted in China, the world's top energy consumer. Comprehensive surveys of SDA in energy studies can be found in [3133].

In conclusion, IDA and SDA have been the most popular methods when dealing with aggregate indicators for energy consumption [9, 10, 31, 32, 63]. The IDA method is less data-intensive, and this aggregation limits policy implications to the particular sectorial or industrial scale [65]. In contrast, the SDA method relies on the input-output (IO) databases aiming to break down observed changes in physical indicators (e.g., energy consumption) into changes in physical and economic indicators based on systematic and comprehensive viewpoints. Therefore, we recommend using the SDA method to deal with energy issues in this empirical study.

\section{Constructing the SDA Method}

The conventional Leontief input-output model is shown as:

$$
x=(I-A)^{-1} y=L y
$$

...where $x$ represents the vector of total output, $y$ represents the final demand vector and $A$ represents the $n \times n$ domestic intermediate coefficients [23]. $L=(I-A)^{-1}$, the $n \times n$ Leontief inverse matrix, accounts for not only the direct production effects through the domestic intermediate coefficients, but also all the indirect production effects in the whole economic process $[19,23]$.

Based on the Input-output theory [24], energy and economy can be modelled by applying the SDA method and combining with energy indicator, as follows $[5,25$, 66-71]:

$$
X=E(I-A)^{-1} y
$$

...where $X$ is total energy consumption; $E=\frac{X}{x}$ is the $1 \times n$ energy intensity vector on industrial scale; and the $n \times 1$ column vector $y$ represents the final demand sectors in the input-output table, which comprised the final consumptions (i.e., government consumptions, urban household consumptions, and rural household consumptions), gross capital formation (i.e., fixed capital formation and inventory increase), and gross imports and exports (i.e., inter-provincial import, international import, inter-provincial export, and international export).

Then $y$ can be further decomposed as the final demand structure $y_{s}$ and the total final demand, whereby 
Table 1. Summary of selected SDA applications in energy studies.

\begin{tabular}{|c|c|c|c|c|}
\hline Year & References & Period & Region & Indicator \\
\hline 1982 & {$[26]$} & $1973-1978$ & Sweden & Energy use \\
\hline 1985 & {$[27]$} & 1966-1980 & Denmark & Energy consumption \\
\hline 1986 & {$[28]$} & 1974-1979 & Saskatchewan, Canada & Energy use \\
\hline 1987 & [29] & 1963-1977 & U.S. & Energy use \\
\hline 1990 & {$[30]$} & 1971-1984 & Taiwan & Energy demand \\
\hline 1991 & {$[34]$} & 1972-1982 & U.S. & Energy use \\
\hline 1994 & {$[35]$} & 1976-1986 & Taiwan & Industrial electricity \\
\hline 1995 & {$[36]$} & 1981-1987 & China & Energy use \\
\hline 1999 & {$[37]$} & 1987-1992 & China & Energy intensity \\
\hline 1999 & {$[38]$} & 1973-1992 & India & Energy consumption \\
\hline 2000 & [39] & 1966-1992 & Denmark & Energy demand \\
\hline 2001 & {$[40]$} & $1985-1990$ & Japan & Energy consumption \\
\hline 2003 & {$[41]$} & 1990 & OECD & Energy consumption \\
\hline 2004 & {$[42]$} & $1985-1990$ & Japan & Energy demand \\
\hline 2004 & [43] & 1995 & EU & Energy intensity \\
\hline 2006 & {$[44]$} & $1996-2000$ & Vietnam & Energy flow \\
\hline 2007 & {$[45]$} & 1970-1995 & Japan & Energy and emission \\
\hline 2007 & {$[46]$} & $1980-2000$ & Korea & Household energy \\
\hline 2009 & {$[47]$} & $1992-2004$ & China & Energy intensity \\
\hline 2009 & {$[48]$} & 1970-1996 & Brazil & Energy use \\
\hline 2009 & [49] & $1997-2002$ & U.S. & Energy use \\
\hline 2010 & {$[50]$} & $1978-2004$ & China & Embodied energy \\
\hline 2010 & {$[51]$} & $1992-2005$ & China & Embodied energy \\
\hline 2010 & {$[52]$} & $1970-1985$ & Japan & Energy demand \\
\hline 2012 & {$[32]$} & $1997-2007$ & China & Energy and emission \\
\hline 2012 & {$[31]$} & $2002-2007$ & China & Energy and emission \\
\hline 2012 & {$[53]$} & $1987-2007$ & China & Energy consumption \\
\hline 2012 & {$[54]$} & $1987-2005$ & China & Energy intensity \\
\hline 2014 & {$[55]$} & $1997-2007$ & China & Energy intensity \\
\hline 2014 & {$[56]$} & $1987-2007$ & China & Energy consumption \\
\hline 2014 & {$[57]$} & $1997-2007$ & China and U.S. & Energy use \\
\hline 2015 & {$[58]$} & $2002-2007$ & China & Energy intensity \\
\hline 2015 & {$[59]$} & $1995-2007$ & Austria & Raw material use \\
\hline 2016 & {$[60]$} & $1990-2010$ & Global & Energy footprint \\
\hline 2016 & {$[61]$} & $1995-2010$ & Thailand & Energy intensity \\
\hline 2017 & {$[62]$} & 2001-2011 & Catalonian, Spain & Energy output \\
\hline 2017 & {$[63]$} & $2007-2012$ & China & Energy and emission \\
\hline 2017 & [64] & $2007-2012$ & China & Energy intensity \\
\hline
\end{tabular}


the latter can be further deposed as per capita final demand $y_{v}$ (i.e., per capita GDP) and population size $P$.

Therefore, $y=P y_{s} y_{v}$

Given the above, the SDA method for energy consumption can be derived as:

$$
X=E \times L \times y_{s} \times y_{v} \times P
$$

Then, the arithmetic in dealing with the aggregate energy consumption indicator between specific time period can be decomposed as:

$\Delta X=\Delta E L y_{s} y_{v} P+E \Delta L y_{s} y_{v} P+E L \Delta y_{s} y_{v} P+E L y_{s} \Delta y_{v} P+E_{s} E_{i} L y_{s} y_{v} \Delta P$

Subsequently,

$$
\Delta X=f(\Delta E)+f(\Delta L)+f\left(\Delta y_{s}\right)+f\left(\Delta y_{v}\right)+f(\Delta P)
$$

Based on the above, changes in total energy consumption $(\Delta X)$ were decomposed into five main influencing factors: energy intensity $(E)-$ eint, Leontief structure $(L)-l s t r$, final demand structure $\left(y_{s}\right)-d s t r$, per capita GDP $\left(y_{v}\right)-p g d p$, and population size $(P)-$ pops.

Advantages of the SDA method also include its ability to show the indirect effects of the final demand sectors on energy consumption $[25,72]$. The $n \times 1$ column vector $y$ can be diagonalized based on the categories of final demand sectors in the input-output table, in order to allocate energy consumption changes caused by final demands by economic sectors [72]. The following equation was derived:

$$
X_{k}=E(I-A)^{-1} y_{k}
$$

...where $y_{k}$ represents the final demand of the $k$ type, $X_{k}$ represents the indirect energy consumption caused by changes in the final demand of the $k$ type.

\section{Data Material}

The data used in this case study, three time-series monetary input-output tables from 2002, 2007, and 2012, were mainly obtained from the "Guangdong Province input-output table." We consolidated and summarized the three input-output tables comprising 42 sectors in 2002, 2007, and 2012 into an input-output table for 27 sectors (Table 2), in order to keep the data set consistent with the energy consumption data of industrial sectors. Data on total population, economic scale, industry-specific energy consumption, and total energy consumption were primarily taken from the "Guangdong Statistical Yearbook" (2002-2013) and the "China Energy Statistical Yearbook" (2002-2013). In addition, we converted the current prices in 2007 and 2012 into 2002 constant prices by using the double deflation method to enhance the comparability of data sources $[66,67]$.

Table 2. Input-output of 27 industries in Guangdong Province.

\begin{tabular}{|c|c|c|c|}
\hline Code & Sector & Code & Sector \\
\hline 1 & Agriculture & 15 & General and specialized equipment manufacturing \\
\hline 2 & $\begin{array}{c}\text { Coal mining and washing, petroleum and natural } \\
\text { gas extraction }\end{array}$ & 16 & Transportation equipment \\
\hline 3 & Metals mining and dressing & 17 & Electrical machinery and equipment manufacturing \\
\hline 4 & Nonmetal and other minerals mining and dressing & 18 & $\begin{array}{c}\text { Communication equipment, computers and other electronic } \\
\text { equipment manufacturing }\end{array}$ \\
\hline 5 & Food production and tobacco processing & 19 & Instruments and office supplies manufacturing \\
\hline 6 & Textile & 20 & Other industrial activities \\
\hline 7 & Clothing and other fiber product & 21 & Electricity production and supply \\
\hline 8 & Wood products & 22 & Production and distribution of gas \\
\hline 9 & Papermaking, printing, cultural, educational and & 23 & Production and distribution of water \\
\hline 10 & Pports articles & 24 & Construction \\
\hline 11 & Petroleum processing and coking & 25 & Transportation, storage and communications \\
\hline 12 & Chemical industry & 26 & Wholesale, retail trades, hotels, catering service \\
\hline 13 & Metal smelting and rolling processing & 27 & Other service activities \\
\hline 14 & Metal products & & \\
\hline
\end{tabular}




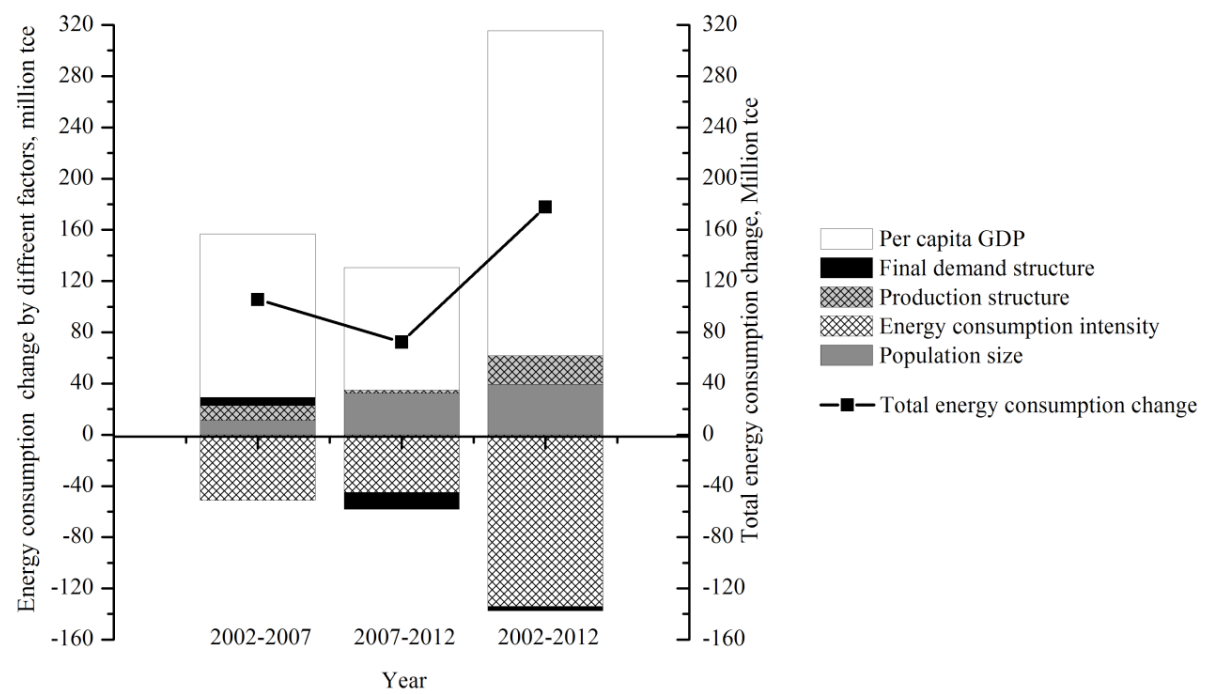

Fig. 4. Structure decomposition analysis on the effects of influencing factors driving energy consumption changes in Guangdong during 2002 to 2012.

\section{Results and Discussion}

During 2002 to 2012, total energy consumption in Guangdong increased rapidly from 113.55 million TCE in 2002 to 219.12 million in 2007, and subsequently to 291.44 million in 2012. The energy consumption increment during the whole research period was 177.89 million TCE, representing an annual growth rate of $2.71 \%$. Guangdong's average annual growth rate is far below China's national average growth rate $4.25 \%$ during the same period (2002-2012). In particular, the increase in total energy consumption between 2002 and 2007 accounted for $59.35 \%$ of the overall increase, but the increment between 2007 and 2012 accounted for $40.65 \%$ of the overall increase during 2002 to 2012 (Fig. 4). It illustrates that energy consumption in Guangdong after the global financial crisis was significantly lower than energy consumption before the global financial crisis.

Firstly, we used the SDA method to quantify the mechanism of the various influencing factors based on Eq. (2)-(6), in order to explain the huge difference in energy consumption before and after the global financial crisis in Guangdong. As shown in Fig. 4, before the global financial crisis (2002-2007), changes in $p g d p$, lstr, pops, and dstr led to an increase of 127.78, 11.25, 11.29 , and 6.47 million TCE, respectively, and changes in eint reduced 51.22 million TCE. After the global financial crisis (2007-2012), changes in pgdp, pops, and lstr increased energy consumption by $95.65,32.45$, and 2.28 million TCE, respectively, and changes in eint and $d s t r$ led to a reduction of 45.02 and 13.05 million TCE, respectively.

Overall analysis of energy consumption increments before and after the global financial crisis indicated that changes in pgdp, pops and lstr led to 253.60, 39.41, and 22.34 million TCE, representing 142.57\%,
$22.15 \%$ and $12.56 \%$ of total energy consumption. Energy consumption mitigation as a result of eint and dstr was 133.95 .47 and 3.53 million TCE, accounting for $75.30 \%$ and $1.98 \%$ of the absolute change in energy consumption. Analysis results show that economic activity $(p g d p)$ and population size (pops) are the main drivers for energy consumption increments in Guangdong. Although production structure (lstr) is still a positive driver for energy consumption increment at present, its contribution has decreased significantly from $10.66 \%$ before the global financial crisis to $3.16 \%$ after the global financial crisis, owing to the continuous improvement toward an energy-saving production structure. Eint is the important factor for restraining energy consumption increments in Guangdong, and its contribution ratio increased from $48.52 \%$ before the global financial crisis to $62.25 \%$ after the global financial crisis. In addition, the effects of $d s t r$ on energy consumption in Guangdong changed from positive (6.12\%) before the global financial crisis to negative $(-18.05 \%)$ after the global financial crisis. Subsequently, it became an important factor for restraining energy consumption increment, indicating the achievement of an optimized energy-saving economic structure after the global financial crisis. Compared with a previous related study conducted in China, the main reasons underlying these energy-related emissions declines were changes in production structure and efficiency gains during 2007-2012. But, taking Guangdong as a case region, one of the top energy consumers in China, energy consumption reductions were mainly contributed by efficiency gains and final demand structure. This significant difference between the national and provincial levels highlighted the importance of the national experience-based learnings as well as provincial case-based empirical studies when developing national and regional sustainable energy strategies. 


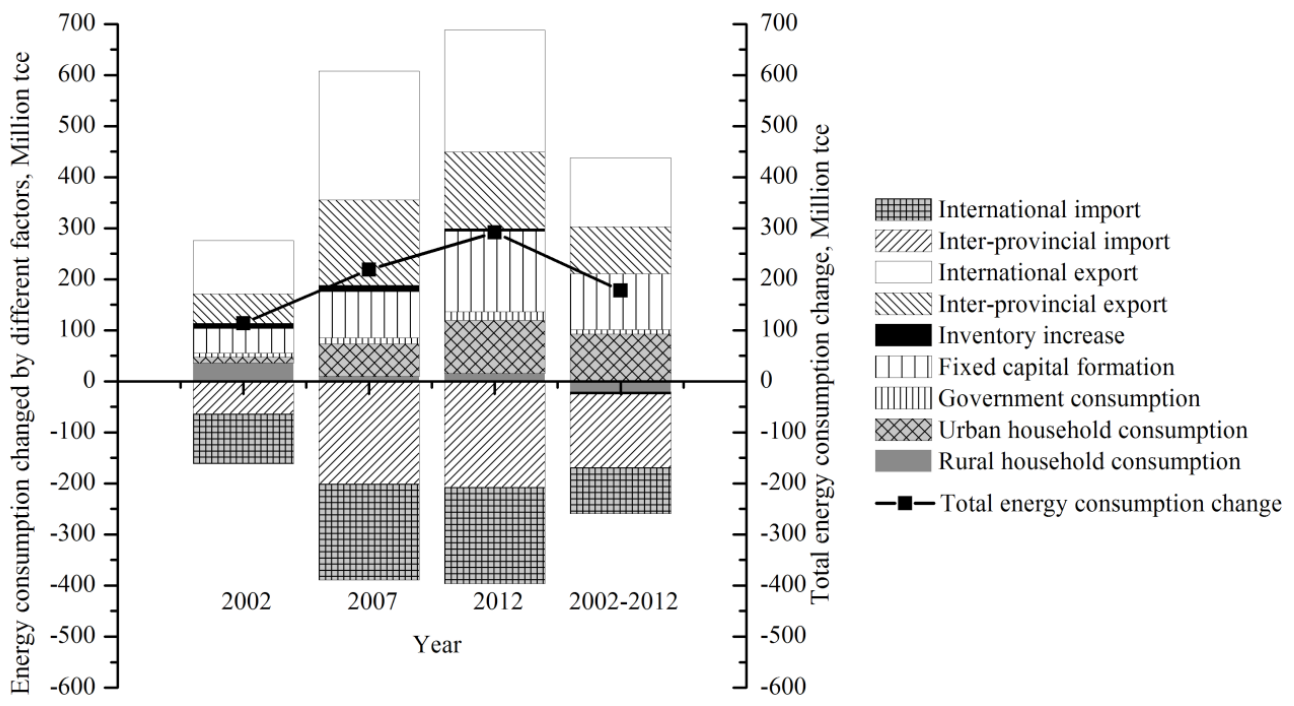

Fig. 5. Allocation of energy consumption changes caused by final demands according to final demand categories in Guangdong during 2002 to 2012

Secondly, we examined the contributions of influencing factors driving energy consumption changes caused by final demands, according to the results of a calculation using Equation (7). Energy consumption increments were mainly caused by international export, inter-provincial export, fixed capital formation, and urban household consumption, whereas energy consumption mitigations were mainly induced by inter-provincial import and international import in Guangdong (Fig. 5).

During 2002 to 2012, 134.40 and 92.33 million TCE of energy consumption increments in Guangdong were caused by changes in international export and inter-provincial export, accounting for $75.55 \%$ and $51.90 \%$ of the total energy consumption, respectively. Meanwhile, 109.34 and 92.86 million TCE increments were caused by fixed capital formation and urban household consumption, representing $55.72 \%$ and $52.59 \%$ of total energy consumption. In contrast, 52.92 and 30.01 million TCE of energy consumption mitigations were caused by the changes in interprovincial import and international import, accounting for $61.47 \%$ and $52.20 \%$ of total energy consumption, respectively.

However, the impacts and influences of various factors on energy consumption are different before and after the global financial crisis (Fig. 5). In 2002 and 2007, before the global financial crisis, international export, inter-provincial export, and fixed capital formation are the main drivers for energy consumption increments in Guangdong. In 2012, after the global financial crisis, international export, fixed capital formation, and inter-provincial export are the main drivers. In deep analysis, energy consumption embodied in international export and inter-provincial export decreased from 420.02 million TCE to 388.64 million TCE after the global financial crisis. In contrast, energy consumption caused by fixed capital formation and urban household consumption rapidly increased from 90.42 million TCE to 157.29 million TCE and from 64.04 million TCE to 104.38 million TCE after the global financial crisis, respectively. After the global financial crisis, China's central government immediately launched the "Four trillion yuan investment stimulus plan" in 2008, which mainly focused on railway, highway, electric power and other large infrastructure construction. The economy of Guangdong continued to develop rapidly due to the national stimulus plan [17]. The gross fixed capital investment increased from 959.695 billion yuan in 2007 to 1930.75 billion yuan in 2012, and the positive effects of fixed capital formation on total energy consumption increased rapidly from $41.27 \%$ in 2007 to $53.97 \%$ in 2012. After the global financial crisis, Guangdong's urbanization level (calculated as the proportion of urban population to permanent population) increased rapidly from $63.14 \%$ in 2007 to $67.40 \%$ in 2012 . Energy consumption in Guangdong caused by urban household consumption along with the rapid urbanization process increased from 64.04 million TCE in 2007 to 104.38 million TCE in 2012.

Guangdong is the most developed province based on manufacturing and import/export, profiting from the economic liberalization and globalization after China's reform and opening-up policy. In other words, economic development of Guangdong is deeply influenced by globalization. Although energy consumption embodied in international export decreased from 252.50 million TCE in 2007 before the global financial crisis to 238.24 million TCE in 2012 afterward, it is still the most significant important driver for energy consumption increments. 


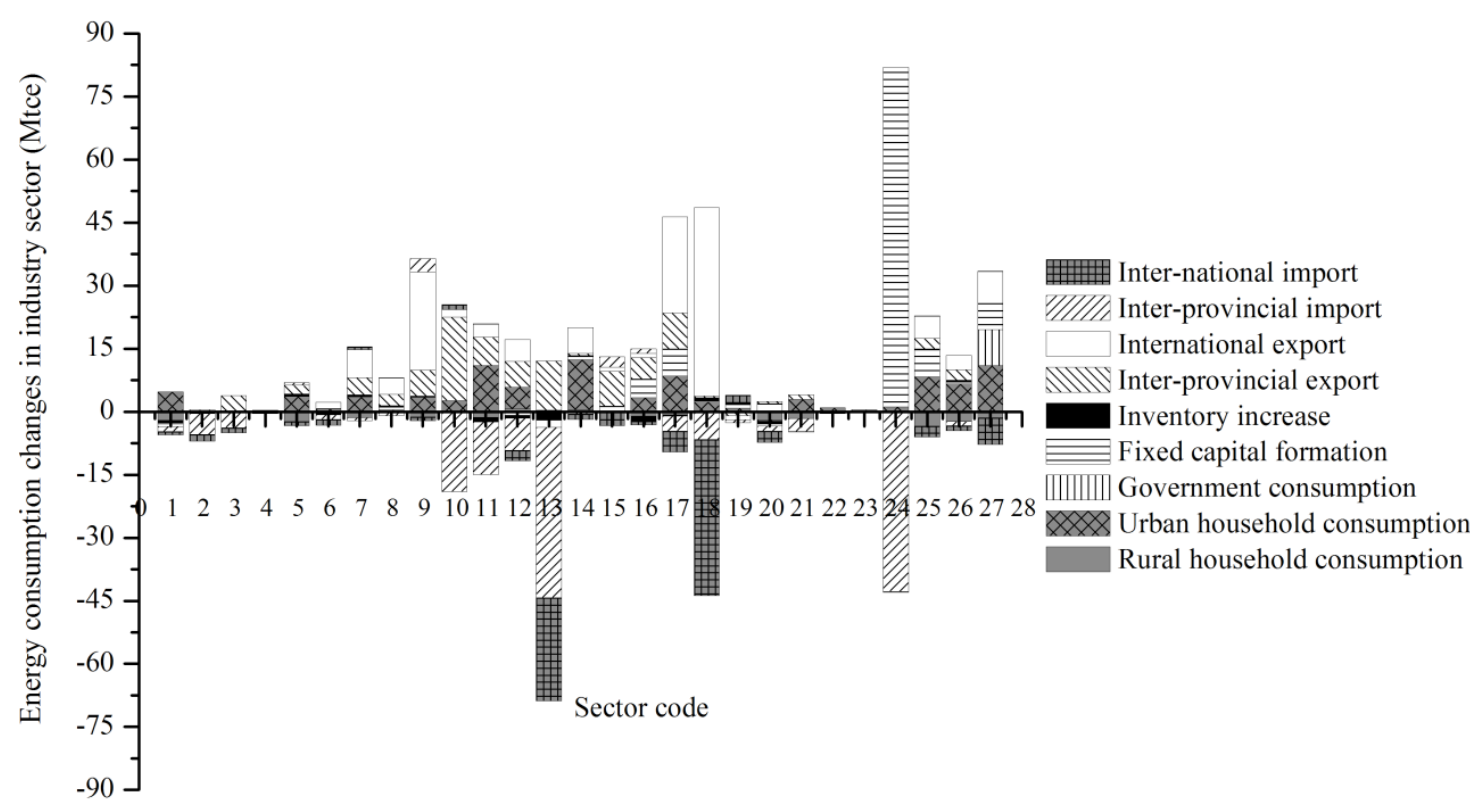

Fig 6. Contributions of different final demand types driving energy consumption changes in the industry sector in Guangdong during 2002 to 2012 (million TCE).

Therefore, Guangdong is the net exporter of embodied energy through international trade. Through comparison and analysis, energy consumption reduction caused by international imports increased from 188.32 million TCE in absolute value in 2007 to 189.06 million TCE in 2012 after the global financial crisis, but energy consumption reduction caused by inter-provincial import increased rapidly from 200.55 million TCE in 2007 to 207.39 million TCE in 2012. Inter-provincial import played a more important effect in energy consumption reduction than international import after the global financial crisis. That is to say, Guangdong's energy-saving achievement is largely due to embodied energy transfers via China's domestic trade.

Finally, we analyzed contributions of different final demand types in driving energy consumption changes in the industry sector in Guangdong during 2002 to 2012 (Fig. 6). During 2002 to 2012, sector codes 25, 21, 11, 13, and 9 were mainly responsible for energy consumption in Guangdong. These five major industries accounted for more than $50 \%$ of the total energy consumption in Guangdong. These energy-intensive sectors should be key industries for energy mitigation in the industrial development in Guangdong in the near future.

During 2002 to 2012, international export and interprovincial export resulted in 134.40 million TCE and 92.33 million TCE of energy consumption increments, respectively. Regarding international export, sector codes 18 (44.84 million TCE), 9 (23.36 million TCE), and 17 (22.84 million TCE) were the main contributors to the embodied energy increments via international trade. Regarding inter-provincial export, sector codes 10 (19.86 million TCE), 13 (11.75 million TCE), 17
(8.58 million TCE), and 15 (8.24 million TCE) were the important drivers for embodied energy increments via China's domestic trade. Inter-provincial import and international import accounted for a reduction of 143.91 and 90.71 million TCE in Guangdong, respectively. Sector codes 24 (42.81 million TCE), 13 (40.60 million TCE), and 10 (18.70 million TCE) mainly contributed to the energy consumption mitigation owing to inter-provincial import via China's domestic trade, whereas sector codes 18 (37.28 million TCE) and 13 (24.49 million TCE) mainly contributed to the mitigation owing to international import. Increases in fixed capital formation resulted in an increase of 109.34 million TCE, accounting for $61.47 \%$ of the total increase. Sector codes 24 (79.73 million TCE), 25 (6.53 million TCE), and 17 (6.51 million TCE) were mainly responsible for the energy consumption increments in Guangdong. Urban household consumption resulted in an increase of 92.86 million TCE, accounting for $52.20 \%$ of the total increase. Sector codes 14 (11.97 million TCE) and 11 (11.04 million TCE), and tertiary industries such as codes 27 (10.95 million TCE) and 25 (8.36 million TCE) were the main contributors.

In our case study the SDA method based on inputoutput theory was used to analyze the influencing mechanism of energy consumption in Guangdong during 2002 to 2012. We consolidated and summarized the three input-output tables comprising 42 sectors in 2002, 2007, and 2012 into an input-output table for 27 sectors, mainly owing to the data limitation. However, the impacts of aggregation issues at the sector and temporal level should be highlighted in empirical SDA studies [32, 73]. International trade and domestic trade jointly played significant effects on the total energy consumption in Guangdong before and after the 
global financial crisis. Energy consumption intensities at sector level used for international and interprovincial trades are the same assumptions in our case study, owing to the data limitation to identify the source and destination of these imported products. However, processing and normal export assumption in the embodied energy analysis were key issues [74]. In fact, a large amount of Guangdong's exports are processing exports whose embodied energy consumption intensity is much lower than the normal exports [74, 75]. In the future, the direct input coefficient matrix in the input-output table should be decomposed to distinguish foreign imports and domestic products [76]. Guangdong's unique features in the international and domestic trades will highlight the importance of energy consumption intensity and trade structure in interpreting the changes in energy consumption in the manufacturing sectors in Guangdong, as well as other manufacturing and export-oriented provinces in China.

\section{Conclusions}

Based on the application of the classic input-output theory and the construction of the energy-economy analysis framework, the systematic SDA method was conducted in order to uncover the drivers for energy consumption in Guangdong before and after the global financial crisis during 2002 to 2012. The main conclusions are as follows: Economic activity ( $p g d p)$ and population size (pops) are the main drivers for energy consumption increments in Guangdong. Energy consumption intensity (eint) is the most important factor restraining energy consumption increment. The effects of final demand structure (dstr) on total energy consumption transformed from positive before the global financial crisis between 2002 and 2007 to negative after the global financial crisis between 2007 and 2012.

Analysis of allocation of energy consumption changes caused by final demands shows that international export and import and inter-provincial export and import had significant effects on changes in energy consumption in Guangdong. Although energy consumption embodied in international export decreased after the global financial crisis, it is still the most significant important driver for the energy consumption increments. Guangdong is a net exporter of embodied energy through international trade. Structural decomposition analysis on the effects of different final demand in the industry sector indicates that, for international export trades, the electronics and machinery industries, and low value-added laborintensive industries are the main contributors. Energy consumption reduction caused by inter-provincial import increased rapidly, and it played a more important effect in energy consumption reduction than international import after the global financial crisis. Guangdong's energy-saving achievement is largely due to embodied energy transfers via China's domestic trade. Future energy-saving development should emphasize more on the continuous reduction of energy consumption intensity, optimization of energy structure, and upgrading technology. At present, as well as in the mid to long term, energy-intensive industries should be the key industries for energy conservation in the development and distribution of industries in Guangdong Province. The reduction of energy consumption intensity should focus on optimizing industry structures to reduce industrial consumption and monitoring high consumption sectors.

\section{Acknowledgements}

This work was supported by the National Natural Science Foundation of China (41501144, 41671130, 41671128), the Xinjiang Laboratory of Lake Environment and Resources in Arid Zone, Xinjiang Uygur Autonomous Region Key Laboratory Foundation (XJDX0909-2015-03), the Research Centre for Urban Development of the Silk Road Economic Belt, the "13th Five-Year" Plan for Key Discipline Bidding Project, Xinjiang Normal University (No: 17SDKD0703), the Xinjiang Normal University Doctoral Research Foundation (XJNUBS1538), the Hundreds of Young Doctors Introduction Program of Xinjiang, Xinjiang Normal University (BS2016004), the GDAS' Project of Science and Technology Development (2016GDASRC-0101, 2017GDASCX-0101, 2018GDASCX-0101, 2019GDASYL-0302001).

\section{Conflict of Interest}

The authors declare no conflict of interest.

\section{References}

1. CHU S., MAJUMDAR A. Opportunities and challenges for a sustainable energy future. Nature, 488, 294, 2012.

2. BP. Statistical Review of World Energy. 2017.

3. WANG C., WANG F. China can lead on climate change. Science, 357, 764, 2017.

4. PETERS G.P., MARLAND G., LE QU RC., BODEN T., CANADELL J.G., RAUPACH M.R. Rapid growth in $\mathrm{CO}_{2}$ emissions after the 2008-2009 global financial crisis. Nature Clim Change, 2, 2, 2012.

5. MI Z., MENG J., GUAN D., SHAN Y., SONG M., WEI Y.-M., LIU Z., HUBACEK K. Chinese $\mathrm{CO}_{2}$ emission flows have reversed since the global financial crisis. Nature Communications, 8, 1712, 2017.

6. L PEZ L.-A., ARCE G., ZAFRILLA J. Financial Crisis, Virtual Carbon in Global Value Chains, and the Importance of Linkage Effects. The Spain-China Case. Environ Sci Technol, 48, 36, 2014.

7. MYERS J.G., NAKAMURA L.I. Saving energy in manufacturing: the post-embargo record: Ballinger, 1978. 
8. BOSSANYI E. UK primary energy consumption and the changing structure of final demand. Energy Policy, 7, 253, 1979.

9. ANG B.W., LEE S.Y. Decomposition of industrial energy consumption: Some methodological and application issues. Energy Econ, 16, 83, 1994.

10. ANG B.W. Decomposition methodology in industrial energy demand analysis. Energy, 20, 1081, 1995.

11. XU X.Y., ANG B.W. Analysing residential energy consumption using index decomposition analysis. ApEn, 113, 342, 2014.

12. ANG B.W., LIU F.L. A new energy decomposition method: perfect in decomposition and consistent in aggregation. Energy, 26, 537, 2001.

13. CHOI K.-H., ANG B.W. Decomposition of aggregate energy intensity changes in two measures: ratio and difference. Energy Econ, 25, 615, 2003.

14. ANG B.W., XU X.Y. Tracking industrial energy efficiency trends using index decomposition analysis. Energy Econ, 40, 1014, 2013.

15. WANG C., WANG F., ZHANG H., YE Y., WU Q., SU Y. Carbon emissions decomposition and environmental mitigation policy recommendations for sustainable development in Shandong province. Sustainability, 6, 8164, 2014.

16. WANG C., ZHANG X., WANG F., LEI J., ZHANG L. Decomposition of energy-related carbon emissions in Xinjiang and relative mitigation policy recommendations. Frontiers of Earth Science, 9, 65, 2015.

17. WANG F., WANG C., SU Y., JIN L., WANG Y., ZHANG $X$. Decomposition Analysis of Carbon Emission Factors from Energy Consumption in Guangdong Province from 1990 to 2014. Sustainability, 9, 274, 2017.

18. ANG B.W. LMDI decomposition approach: A guide for implementation. Energy Policy, 86, 233, 2015.

19. WANG H., ANG B.W., SU B. Assessing drivers of economy-wide energy use and emissions: IDA versus SDA. Energy Policy, 107, 585, 2017.

20. ROSE A., CASLER S. Input-Output Structural Decomposition Analysis: A Critical Appraisal. Econ Systems Res, 8, 33, 1996.

21. HOEKSTRA R., VAN DEN BERGH J.C.J.M. Comparing structural decomposition analysis and index. Energy Econ, 25, 39, 2003.

22. WANG C., WANG F. Structural decomposition analysis of carbon emissions and policy recommendations for energy sustainability in Xinjiang. Sustainability, 7, 7548, 2015.

23. LEONTIEF W. Quantitative Input and Output Relations in the Economic Systems of the United States. RvE\&S, 18, $105,1936$.

24. LEONTIEF W. Environmental Repercussions and the Economic Structure: An Input-Output Approach. RvE\&S, 52, 262, 1970.

25. WANG C., WANG F., ZHANG X., ZHANG H. Influencing mechanism of energy-related carbon emissions in Xinjiang based on the input-output and structural decomposition analysis. J Geogr Sci, 27, 365, 2017.

26. ÖSTBLOM G. Energy use and structural changes: Factors behind the fall in Sweden's energy output ratio. Energy Econ, 4, 21, 1982.

27. PL GER E. The Effects of Structural Changes on Danish Energy Consumption. Conference The Effects of Structural Changes on Danish Energy Consumption, Berlin, Heidelberg. Springer Berlin Heidelberg, p. 211.

28. GOULD B.W., KULSHRESHTHA S.N. An interindustry analysis of structural change and energy use linkages in the Saskatchewan economy. Energy Econ, 8, 186, 1986.

29. GOWDY J.M., MILLER J.L. Technological and Demand Change in Energy Use: An Input-Output Analysis. Environment and Planning A: Economy and Space, 19, 1387, 1987.

30. CHEN C.Y., ROSE A. A Structural Decomposition Analysis of Changes in Energy Demand in Taiwan: 19711984. Energy J, 11, 127, 1990.

31. SU B., ANG B.W. Structural decomposition analysis applied to energy and emissions: Some methodological developments. Energy Econ, 34, 177, 2012.

32. SU B., ANG B.W. Structural decomposition analysis applied to energy and emissions: aggregation issues. Econ Systems Res, 24, 299, 2012.

33. LENZEN M. Structural analyses of energy use and carbon emissions - an overview. Econ Systems Res, 28, 119, 2016.

34. ROSE A., CHEN C.Y. Sources of change in energy use in the U.S. economy, 1972-1982: A structural decomposition analysis. Resources Energy, 13, 1, 1991.

35. CHEN C.-Y., WU R.-H. Sources of change in industrial electricity use in the Taiwan economy, 1976-1986. Energy Econ, 16, 115, 1994.

36. LIN X., POLENSKE K.R. Input-Output Anatomy of China's Energy Use Changes in the 1980s. Econ Systems Res, 7, 67, 1995.

37. GARBACCIO R.F., HO M.S., JORGENSON D.W. Why Has the Energy-Output Ratio Fallen in China? The Energy Journal, 20, 63, 1999.

38. MUKHOPADHYAY K., CHAKRABORTY D. India's Energy Consumption Changes during 1973/74 to 1991/92. Econ Systems Res, 11, 423, 1999.

39. JACOBSEN H.K. Energy Demand, Structural Change and Trade: A Decomposition Analysis of the Danish Manufacturing Industry. Econ Systems Res, 12, 319, 2000.

40. KAGAWA S., INAMURA H. A Structural Decomposition of Energy Consumption Based on a Hybrid Rectangular Input-Output Framework: Japan's Case. Econ Systems Res, 13, 339, 2001.

41. DE NOOIJ M., VAN DER KRUK R., VAN SOEST D.P. International comparisons of domestic energy consumption. Energy Econ, 25, 359, 2003.

42. KAGAWA S., INAMURA H. A Spatial Structural Decomposition Analysis of Chinese and Japanese Energy Demand: 1985-1990. Econ Systems Res, 16, 279, 2004.

43. ALC NTARA V., DUARTE R. Comparison of energy intensities in European Union countries. Results of a structural decomposition analysis. Energy Policy, 32, 177, 2004.

44. THI ANH TUYET N., ISHIHARA K.N. Analysis of changing hidden energy flow in Vietnam. Energy Policy, 34, 1883, 2006.

45. OKUSHIMA S., TAMURA M. Multiple calibration decomposition analysis: Energy use and carbon dioxide emissions in the Japanese economy, 1970-1995. Energy Policy, 35, 5156, 2007.

46. PARK H.-C., HEO E. The direct and indirect household energy requirements in the Republic of Korea from 1980 to 2000 - An input-output analysis. Energy Policy, 35, 2839, 2007.

47. CHAI J., GUO J.-E., WANG S.-Y., LAI K.K. Why does energy intensity fluctuate in China? Energy Policy, 37, 5717, 2009.

48. WACHSMANN U., WOOD R., LENZEN M., SCHAEFFER R. Structural decomposition of energy use in Brazil from 1970 to 1996. ApEn, 86,578,2009. 
49. WEBER C.L. Measuring structural change and energy use: Decomposition of the US economy from 1997 to 2002. Energy Policy, 37, 1561, 2009.

50. CAO S., XIE G., ZHEN L. Total embodied energy requirements and its decomposition in China's agricultural sector. Ecolog Econ, 69, 1396, 2010.

51. LIU H., XI Y., GUO J.E., LI X. Energy embodied in the international trade of China: An energy input-output analysis. Energy Policy, 38, 3957, 2010.

52. OKUSHIMA S., TAMURA M. What causes the change in energy demand in the economy?: The role of technological change. Energy Econ, 32, S41, 2010.

53. FAN Y., XIA Y. Exploring energy consumption and demand in China. Energy, 40, 23, 2012.

54. XIA Y., YANG C., CHEN X. Structural decomposition analysis on China's energy intensity change for 1987-2005. Journal of Systems Science and Complexity, 25, 156, 2012.

55. ZENG L., XU M., LIANG S., ZENG S., ZHANG T. Revisiting drivers of energy intensity in China during 1997-2007: A structural decomposition analysis. Energy Policy, 67, 640, 2014.

56. ZHANG H., LAHR M.L. China's energy consumption change from 1987 to 2007: A multi-regional structural decomposition analysis. Energy Policy, 67, 682, 2014.

57. LIU H., POLENSKE K.R., GUILHOTO J.J.M., XI Y. Direct and indirect energy use in China and the United States. Energy, 71, 414, 2014.

58. XIA Y., FAN Y., YANG C. Assessing the impact of foreign content in China's exports on the carbon outsourcing hypothesis. ApEn, 150, 296, 2015.

59. WENZLIK M., EISENMENGER N., SCHAFFARTZIK A. What Drives Austrian Raw Material Consumption?: A Structural Decomposition Analysis for the Years 1995 to 2007. Journal of Industrial Ecology, 19,814,2015.

60. LAN J., MALIK A., LENZEN M., MCBAIN D., KANEMOTO K. A structural decomposition analysis of global energy footprints. ApEn, 163, 436, 2016.

61. SUPASA T., HSIAU S.-S., LIN S.-M., WONGSAPAI W., WU J.-C. Has energy conservation been an effective policy for Thailand? An input-output structural decomposition analysis from 1995 to 2010. Energy Policy, 98, 210, 2016.

62. LLOP M. Changes in energy output in a regional economy: A structural decomposition analysis. Energy, 128, 145, 2017.

63. SU B., ANG B.W. Multiplicative structural decomposition analysis of aggregate embodied energy and emission intensities. Energy Econ, 65, 137, 2017.
64. WANG H., ANG B.W., SU B. Multiplicative structural decomposition analysis of energy and emission intensities: Some methodological issues. Energy, 123, 47, 2017.

65. WANG C., WANG F., ZHANG H. The process of energyrelated carbon emissions and influencing mechanism research in Xinjiang. Acta Ecol Sin, 36, 2151, 2016.

66. MINX J.C., BAIOCCHI G., PETERS G.P., WEBER C.L., GUAN D., HUBACEK K. A "Carbonizing Dragon": China's Fast Growing $\mathrm{CO}_{2}$ Emissions Revisited. Environ Sci Technol, 45, 9144, 2011.

67. PETERS G.P., WEBER C.L., GUAN D., HUBACEK $\mathrm{K}$. China's Growing $\mathrm{CO}_{2}$ Emissions A Race between Increasing Consumption and Efficiency Gains. Environ Sci Technol, 41, 5939, 2007.

68. DUARTE R., PINILLA V., SERRANO A. Income, Economic Structure and Trade: Impacts on Recent Water Use Trends in the European Union. Sustainability, 10, 205, 2018.

69. ROSON R., SARTORI M. A Decomposition and Comparison Analysis of International Water Footprint Time Series. Sustainability, 7, 5304, 2015.

70. SUPASA T., HSIAU S.-S., LIN S.-M., WONGSAPAI W., WU J.-C. Household Energy Consumption Behaviour for Different Demographic Regions in Thailand from 2000 to 2010. Sustainability, 9, 2328, 2017.

71. WANG C., ZHANG X., ZHANG H., WANG F. Influencing mechanism of energy-related carbon emissions in Xinjiang based on the input-output and structural decomposition analysis. Acta Geographica Sinica, 71, 1105, 2016.

72. LIANG S., ZHANG T. What is driving $\mathrm{CO}_{2}$ emissions in a typical manufacturing center of South China? The case of Jiangsu Province. Energy Policy, 39, 7078, 2011.

73. SU B., HUANG H.C., ANG B.W., ZHOU P. Input-output analysis of $\mathrm{CO}_{2}$ emissions embodied in trade: The effects of sector aggregation. Energy Econ, 32, 166, 2010.

74. SU B., ANG B.W., LOW M. Input-output analysis of $\mathrm{CO}_{2}$ emissions embodied in trade and the driving forces: Processing and normal exports. Ecolog Econ, 88, 119, 2013.

75. SU B., THOMSON E. China's carbon emissions embodied in (normal and processing) exports and their driving forces, 2006-2012. Energy Econ, 59, 414, 2016.

76. CHEN B., LI J.S., CHEN G.Q., WEI W.D., YANG Q., YAO M.T., SHAO J.A., ZHOU M., XIA X.H., DONG K.Q., XIA H.H., CHEN H.P. China's energy-related mercury emissions: Characteristics, impact of trade and mitigation policies. Journal of Cleaner Production, 141, 1259, 2017. 